\title{
Big Boy. Smarts So Big, Senses So Little: The "theoretical" science of the respectable physicist Prof. Dr. J. Robert Oppenheimer of the Institute for Advanced Study in Princeton, and 60,000 Hiroshima funerals
}

\author{
Camille Akmut
}

\begin{abstract}
His smarts so great, his senses so little... A cautionary tale for all of computer science! And, in particular, those computer scientists who see no moral dilemmas in working for various 'big tech' companies, or States.
\end{abstract}


Non-dedication to a certain German physicist-turned-historian-for-betterand-worse, with a feverish fixation on Einstein, and who conceives of his not-respectable Institute as a place for "basic" science, in the humanities... (This great, great fool.) - so, he told an investor from Switzerland, who seemed, himself, much more concerned with the buildings, or real estate, than with the science. (Bless him, what else.)

Perhaps, this gentle and bon-vivant investor had plans to open up a casino or retreat spa for the upper classes in the middle of Dahlem... 




Figure 1: Alain Resnais' Hiroshima mon amour (1959)

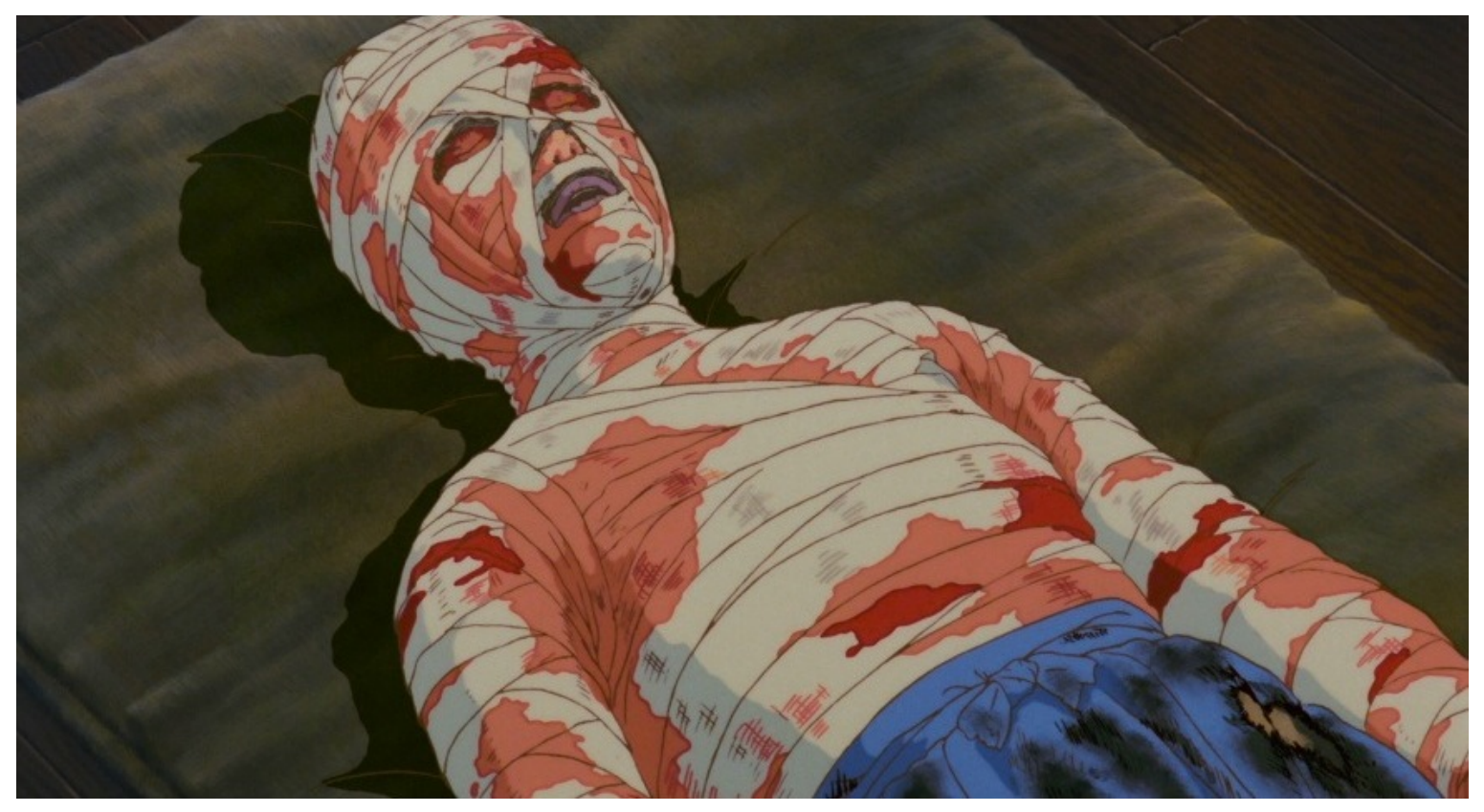

Figure 2: Isao Takahata's Grave of the Fireflies (1988) 


\section{Introduction : the role of history}

How do we render correctly events such as an atomic bomb dropped on human beings - so that it won't happen again? In pictures? In diagrams ${ }^{1}$ ? In paintings like Guernica? Imagination? In numbers? In the equations that underlied them? In poems? In film? Songs?

In his first feature film, Hiroshima mon amour, the endlessly great Alain Resnais, not many directors can be named of his caliber, had done so in the style that was characteristic of his work on memories and the past $^{2}$, by superimposing images of a couple embracing and an empty city (that of Hiroshima). Because, we are not an expert on the effects of atomic bombs on the human body, and never wish to be, we can only wonder : do bodies, flesh and bones melt, and become one with the city, stones and asphalt, dust?

In the 1988 Grave of the Fireflies, Studio Ghibli director Isao Takahata left the poetic for the real in his descriptions of the firebombing of Kobe, where bombs had been dropped from the sky that did not hold uranium, but fire : a boy looks onto his mother, unfathomable, inhuman...

Are we approaching the contents of the dreams of the Prof. Oppenheimer, when we look at images such as these and don't look away?

As for us historians, who are not amputated of a sociological eye, or vision, we prefer to look at people and their sociological characteristics, of which Durkheim had already highlighted in the 19th century two major components : family and education. "Nothing is more important".

This is a lesson that our modern Royal historians - both in the sense of their social origins and their styles and preoccupations - have not quite learned yet... From Dahlem to Vienna, where once nobility had lived and now new nobility lives...

The Prof. Dr. Oppenheimer...

His smarts so great, his senses so little... He deserved much more than a kick : 60,000 of them, according to figures, one for every death. But, what good is judging from the comfort of the present? Such was never the role of history.

It is, however, the role of history, or rather historians to look back at the past as some sort of mirror, if not warning to us : and, in this past, we see many, many reflections of our present times...

(We could not blame anyone for thinking idealistically that knowledge was purely cumulative, and with it came irreversible advancement. ${ }^{3}$ )

\footnotetext{
${ }^{1}$ Such diagrams, including a reverse-engineered one of "Little Boy", can be found in the annex of Ray Monk's biography of Oppenheimer, for instance. (Monk 2012.)

${ }^{2} \mathrm{~A}$ technique shared with Chris Marker, this other great left-bank filmmaker, and analyzer of dreams and memories.

${ }^{3}$ The development of science, and knowledge from it, is rendered correctly in the book The Structure of Scientific Revolutions by Thomas Kuhn.
} 
Mark Weber, along with many others, wrote that a sound knowledge of history was the best tool to predict the future : we can only hope that of Oppenheimer is not ours - while expecting worse.

The cautionary tale of the respectable "theoretical" physicist Prof. Dr. J. Robert Oppenheimer is rendered here for this reason.

"Oppenheimer was overeducated", in many fields, his own, and those that lied outside of the academic tradition, observed Nobel Prize winner in Physics Isidor Rabi ${ }^{4}$. But, education, obviously is not enough! It was not enough, in the most obvious ways, in the case of this physicist.

And, neither was it in the case of the geophysicist Francis Birch, who oversaw the development of with atomic bomb with cruel codename "Little Bomb". Or, Edward Teller.

"Intelligence without heart is sterile", this quote, that we have already cited many times, and whose origins escapes us, is not one that can be found in any physics or computer science books, even though it should be an epitaph to any and all of them.

This big boy of sixteen feet tall Oppenheimer... who was laughed out of the White House like the fool that he was, once he understood - what he had done, to himself, to others, and what they had done to him...

\footnotetext{
${ }^{4}$ Rabi 1969. (Rabi was a close colleague of Oppenheimer.)
} 


\section{Social origins that make blind}

In addition to the 60,000 deaths caused by "Little Boy", which is to say by our "big boy" (smarts so great, senses so little), another 60,000 injuries were reported. How many of those included blindness?

We are tired, so tired of reporting on the same social origins, again and again, with the same consequences, again and again, that : it will come as perhaps no great surprise to those who have read our studies on the new sciences and technologies of our own times, days, that our "big boy", too big for his size, the respectable physicist Prof. Dr. J. Robert Oppenheimer, also came from these same oh-so fine upper-classes...

And, we do not even need to look up biographies of him, whose covers speak variously of "tragedy" and "agony", to write of them in general terms, though we will come to the fine print, the one that Oppenheimer himself didn't read, later :

Geographical seclusion precedes social exclusion. Or, perhaps we should say "exclusive" ... These social origins are always the same, and always, almost, lead to similar results, which are a real, lived sense of living "outside the world" - the common world of common folks.

Social origins that make blind, we write... to the struggles, and the pains of "others", outside; their windows, their walls.

Death by fire, or radiation... No more painful death perhaps. And, in his dreams, did the respectable Prof. Dr. J. Robert Oppenheimer, finally, hear them, and see them scream? (40,000 were average civilians.) And, in how many dreams, and nights? 60,000, or 40,000?

But, in the case of the young J. Robert Oppenheimer, to the blinds of his social origins were added the blinds of the scholarly world, whose own origins we have described elsewhere, pointing to their relevance for our current times, and scholars...

Oppenheimer had all the right titles, and all the right credentials, had gone to all the right schools; and where did things go wrong?

Was it in Cambridge? Was it at Harvard? Was it in Princeton? Was it in Goettingen, perhaps?

Where did things go so wrong... That an adult had senses of a boy.

Did none of his many teachers, tell him of Antigone? Dante's The Divine Comedy? The social portraits of Balzac or Flaubert, in which regrets and human tragedy are everywhere? The paintings of painters Grosz, in which the human ruins of wars too are everywhere and put on display for everyone to see, or those of Kokoschka, whose rippled effects are like the real effects of atomic bombs on human beings? Or the Dada films of the time, unreasonable because "reason was lost"? Or the antiaudience theater of Berthold Brecht? Or, the two dialogues on love by Plato, and the unspeakable vices of the Greeks? Not even at Cambridge? This immeasurable fool of many useless titles, and credentials. 


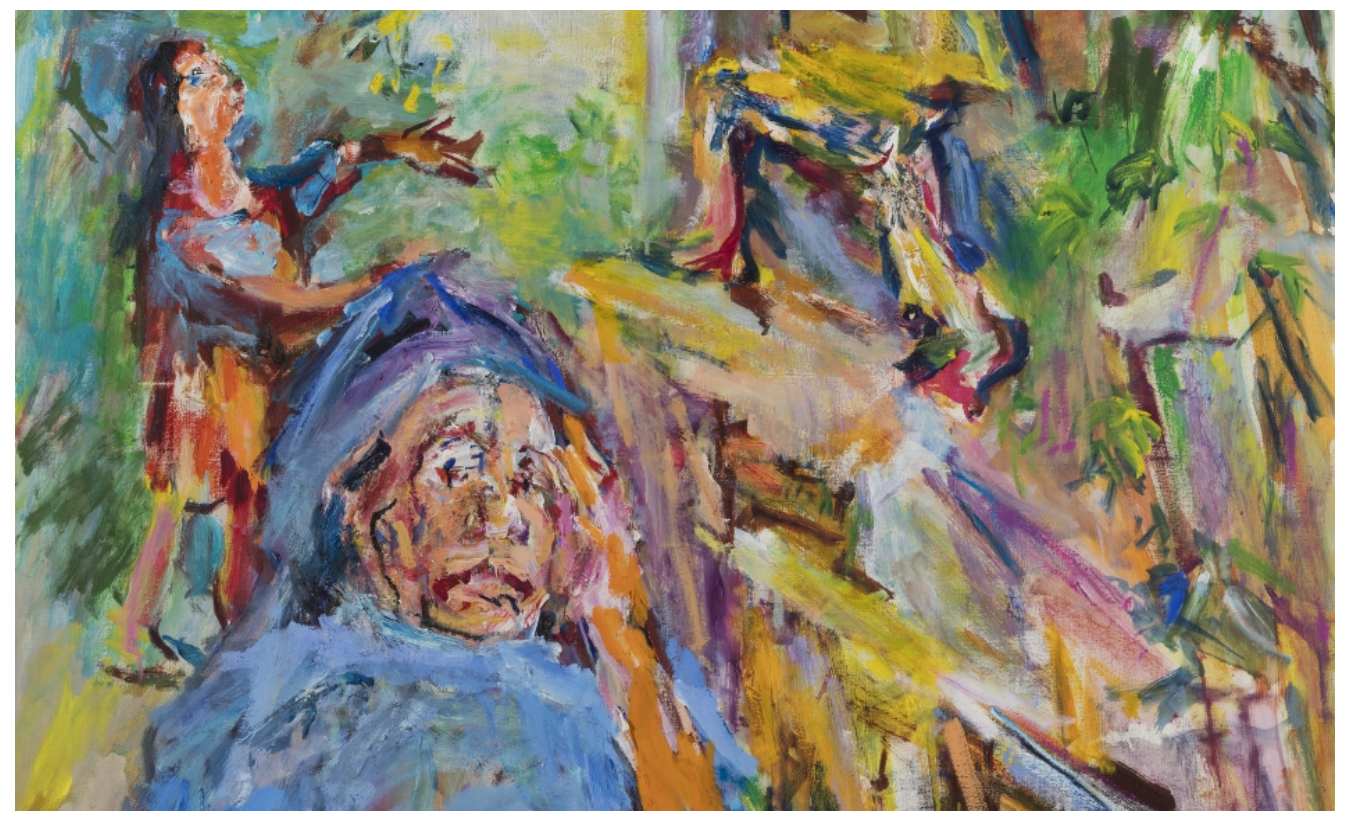

Figure 3: Oskar Kokoschka, Peer Gynt (1972)

The truth - the only truth - of J. Robert Oppenheimer is that he was "undereducated" - grossly, grossly undereducated.

He had received none of the education that matters; and, his purported "overeducation" in far-eastern religions had helped none, and had made no difference; other than it had made it easier for him to think of things far away from home, and himself; and, others.

It was in the extraordinarily tasteful and expensively furnished apartment in West 94th Street that, on 22 April 1904, J. Robert Oppenheimer was born. To help look after the baby, the Oppenheimers employed a nursemaid and, later, a governess. They also employed a cook, a chauffeur and three live-in maids to help Ella look after the apartment. (...) 'My life as a child did not prepare me in any way for the fact that there are cruel and bitter things,' Oppenheimer later recalled. His parents, particularly his mother, saw to it that everything and everyone with whom he came into contact was refined, tasteful and pleasant. From everything discordant, ugly or unpleasant he was shielded and protected. ${ }^{5}$

This barely respectable professor of some strange "theoretical", but physical science... Whose very real, non-theoretical effects he then finally came to recognize, see. Only, too late! Too late... Had he had any other backgrounds, education perhaps... Perhaps. 60,000 perhaps...

\footnotetext{
${ }^{5}$ Monk 2012. Chapter 2: "Childhood".
} 


\section{3 "Postwar activities": A fool is laughed out...}

And, now, look, what this brilliant man from Cambridge and what-not, and later of Princeton, got for welcome when he complained :

On 25 October 1945 President Harry S. Truman received Oppenheimer in the Oval Office; the physicist had requested the meeting in an effort to persuade the president to support international controls on nuclear weapons. Truman disarmed Oppenheimer by asking when the latter thought the Russians would develop a nuclear weapon; Oppenheimer replied that he did not know, to which Truman interjected: "Never!"

Sensing a lack of urgency in the U.S. leader, and perhaps a little overwhelmed by their first meeting, Oppenheimer confided, "Mr. President, I feel I have blood on my hands." The remark infuriated Truman who bluntly replied (as he later told David Lilienthal, chairman of the Atomic Energy Commission), that "the blood is on my hands, let me worry about that," smoothly ejected the physicist and instructed Secretary of State Dean Acheson never to bring "that son of a bitch in this office ever again." 6

This is truly the fate of all physicists, and computer scientists, and mathematicians, who did not give enough thought about the social, to not say sociological characteristics of their employers. - some did not care, or "bother", some regretted it later like Oppenheimer did, and some knew and wanted it, like Edward Teller for instance ${ }^{7}$.

It will never end differently, and you will be no exception : those who work on similarly morally ambiguous projects, we cannot warn them enough... They are lackeys and slaves to their masters. Lap dogs, fed, bathed and brushed at first... And, later? You already know.

And, we will forgo a conclusion, for what conclusion can there be for a story that has no end?

We do so because we already know that we, we and our successors, will need to write the same exact stories, about Google and Facebook and Palantir and Tesla, and their successors; and bubbly, fresh-faced graduates from MIT, Stanford or Berkeley; and their social origins; and the "abstract", "theoretical" or indeed "basic" sciences that came out of them, and their abstract minds.

\footnotetext{
${ }^{6}$ Ham 2015b. See also Ham 2015.

${ }^{7}$ The modern-day equivalents of which are found in figures such as Yann LeCun, Andrej Karpathy, Geoff Hinton or Aleksandr Kogan - to say nothing of Mr. Zuckerberg or Mr. Pichai or even Ms. Sandberg... The list is long, the circles are many.
} 
In writing these lines, we feel a real sense that it is not enough. That knowledge is not enough?

But, we will not leave without answers, or recommendations : create proper curricula for your discipline, such that your scientists will not go out in the world empty-headed like Oppenheimer did, who had received much education, but none that mattered, none on the world outside, of which he was deprived by his own family, and later teachers; and, so that there will no more Oppenheimer's; and, so, that, no one will have to be among, or attend, or write about 60,000 deaths and 60,000 funerals in Hiroshima...; and, so that no one will have to burst into tears, like the modern female heroine in Hiroshima mon amour, who, like Oppenheimer must have done alone with his many regrets, screamed: "I was so young once!" ... 


\section{References}

- Takahata, Isao. 1988. Grave of the Fireflies. Studio Ghibli.

Description : the firebombing of Kobe, and the not-so-funny nor not-sotheoretical effects of our new sciences and technologies. ("Gadgets" are only funny, or "nerdy", until they fall on your head, and split it open.)

- Resnais, Alain. 1959. Hiroshima mon amour.

Description : the past, or the present?

- Resnais, Alain. 1956. Nuit et Brouillard.

Description : god knows a many respectable professors and doctors, from philosophy to law to medicine, had experimented with the real fruits of not-so- "theoretical" science here, too.

- Marker, Chris. 1962. La Jetee.

Description : the cruelty of time : it only flows in one way?

—. 2019. "'Average intellectuals' and the Middle ages : an introduction with translation, and apparatus."

-. 2019. "Tech dogma \# 1 : The Great Separation, between the "technical" and the "political". Documents towards a history."

Ham, Paul. 2015. Hiroshima Nagasaki: The Real Story of the Atomic Bombings and Their Aftermath. Picador.

—. 2015b. "As Hiroshima Smouldered, Our Atom Bomb Scientists Suffered Remorse". Newsweek, 08/05.

Monk, Ray. 2012. Inside The Centre: The Life of J. Robert Oppenheimer. Jonathan Cape.

Description : probably, the only biography of Oppenheimer worth reading. (By the same author of the reference biography of Wittgenstein.)

Rabi, Isidor et al.. 1969. Oppenheimer. Scribner.

Description : posthumous book of memories written by colleagues. 